\title{
O Papel da Imprensa na Alfabetização Tecnológica Para os Usos do Rádio
}

\section{Michele Cruz Vieira}

Doutoranda do Programa de PósGraduação em Comunicação da Universidade Federal Fluminense e Professora do Curso de Comunicação Social da Universidade Gama Filho.
Resumo: A proposta deste artigo é abordar algumas estratégias utilizadas por intelectuais letrados para a difusão da tecnologia do rádio no Brasil a partir de 1923, quando surge a Rádio Sociedade do Rio de Janeiro, primeira emissora regular do país. Com base na análise da revista Radio, percebe-se que há a tentativa de flexibilizar a tecnologia, o que permite ao público criar múltiplas materialidades para aquilo que, posteriormente, seria designado, no singular, como rádio. Nesse momento, Edgar Roquette-Pinto liderava um movimento de alfabetização tecnológica dos cidadãos para a construção de aparelhos, realizado pela intensa troca de informações entre os cidadãos e a emissora recém-inaugurada. A partir da criação de um departamento técnico, a Rádio Sociedade auxiliava tanto aqueles que desejavam construir um rádio com aparatos artesanais quanto os que optavam por um aparelho feito com peças caras e importadas, possibilitando o surgimento de rádios para todos os gostos. A apropriação de aparatos tecnológicos específicos criava ainda ambientes possíveis para o surgimento de múltiplas formas de escuta.

Palavras-Chave: História do radio; Rádio Sociedade do Rio de Janeiro; Tecnologias do Rádio

Abstract: The proposal of this article is to approach some strategies used for intellectual scholars for the diffusion of the technology of the radio in Brazil from 1923, when Rádio Sociedade do Rio de Janeiro, first regular radio of the country. On the basis of the analysis of the magazine Radio, perceives that it has the attempt to spread the technology, what it allows the public to create multiple material forms for what, later, would be assigned person, in the singular, as radio. At this moment, Edgar Roquette-Pinto led a movement of technological literacy of the citizens for the construction of devices, carried through for the intense exchange of information between the citizens and the just-inaugurated radio. From the creation of a department technician, a Rádio Sociedade do Rio de Janeiro in such a way assisted those that they desired to construct to a radio with artisan apparatuses how much the ones that they opted to a device made with expensive and imported parts, making possible the sprouting of radios for all the different technological desires. The appropriation of specific technological apparatuses still created surrounding possible for the sprouting of multiple forms of listening.

Keywords: History of the radio; Rádio Sociedade do Rio de Janeiro; Radio Technologies 
As varas de bambu e as caixas de charuto, que possibilitaram à população mais pobre do subúrbio do Rio de Janeiro construir rádios de galena acessíveis economicamente, dividiam o cenário de crescimento do veículo com aparatos materiais mais sofisticados. Uma grande quantidade e variedade de válvulas,sintonizadores, amplificadores, alto-falantes, dials, fones de ouvido, em sua maioria fabricados por empresas estrangeiras, encontrava-se disponível, possibilitando a construção de aparelhos mais potentes e, em conseqüência, mais caros. Esses tipos de receptores, apropriados por grupos com maior poder aquisitivo, em nada se pareciam fisicamente uns com os outros e menos ainda com os galenas de formato caseiro.

A construção dos rádios, nos anos 1920, comparava-se a uma atividade de mosaico, em que a escolha de cada peça, encaixadas umas às outras, dava origem a uma forma autoral, muito específica, de múltiplas aparências materiais e de diversas potências. Cada um podia possuir, portanto, um rádio completamente diferente dos outros, gerando também uma multiplicidade de possibilidades de escutas em função mesmo da materialidade do objeto.

Os exemplos são inúmeros. Para quem quisesse montar um "Receptor de Crystal", da "Marconiphone", necessitaria de um fone de ouvido para ouvir a programação das emissoras. Como consequência, a escuta materializava-se numa forma individual e num contato total, sem mistura, sobreposição sonora do mundo exterior desse ouvinte com os sons audíveis que percorriam o caminho dos fios até chegar aos fones acoplados aos seus ouvidos.

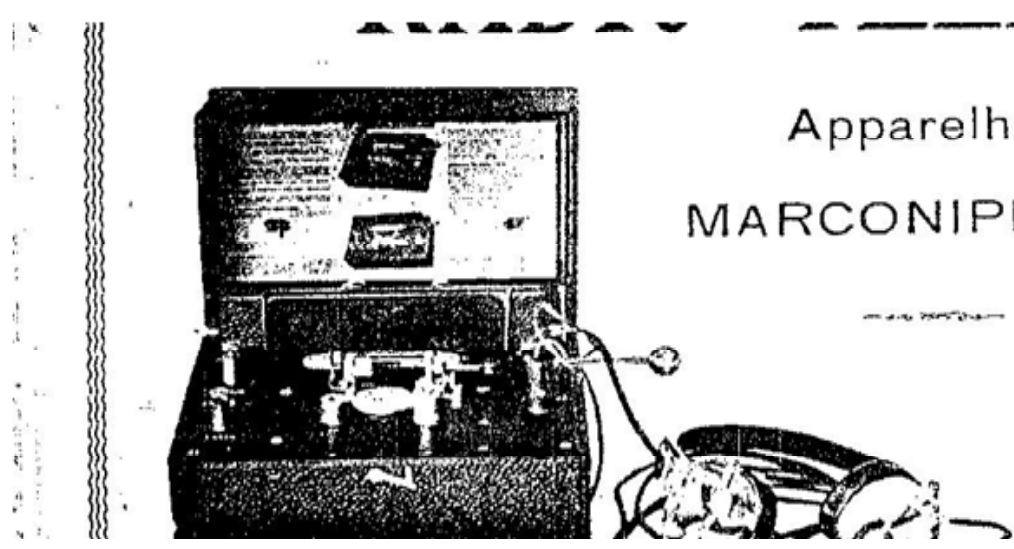

Figura 1 - Fonte: Propaganda da marca Marconiphone, Coletânea da revista Radio, $n$. 13-24, abril a outubro de 1924, disponível no acervo da Rádio MEC.

Já o "Receptor de 2 válvulas, LVR2", também da "Marconiphone", possibilitava a acoplagem de amplificador e alto-falante, transformando a escuta do rádio de individual (com fone de ouvido) em coletiva.
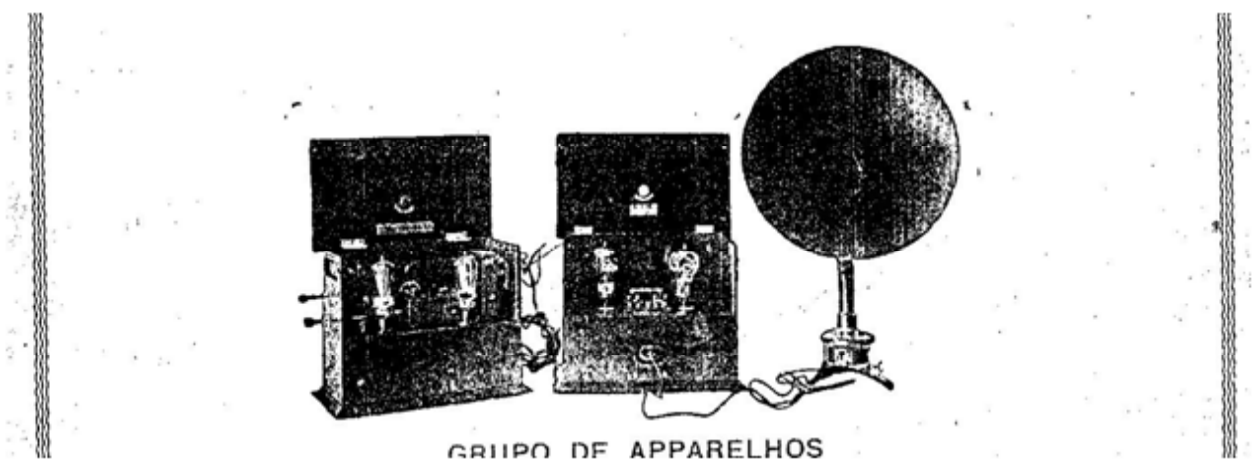

Figura 2 - Fonte: Propaganda da marca Marconiphone, Coletânea da revista Radio, $n$. 13-24, abril a outubro de 1924, disponível no acervo da Rádio MEC.

Em 1926, surge o aparelho de rádio completo, da marca "De Forest", com todas as peças inseridas internamente em um só circuito, dando ao rádio uma aparência 
mais compacta e possibilitando que fosse transportado mais facilmente de um cômodo a outro da casa.

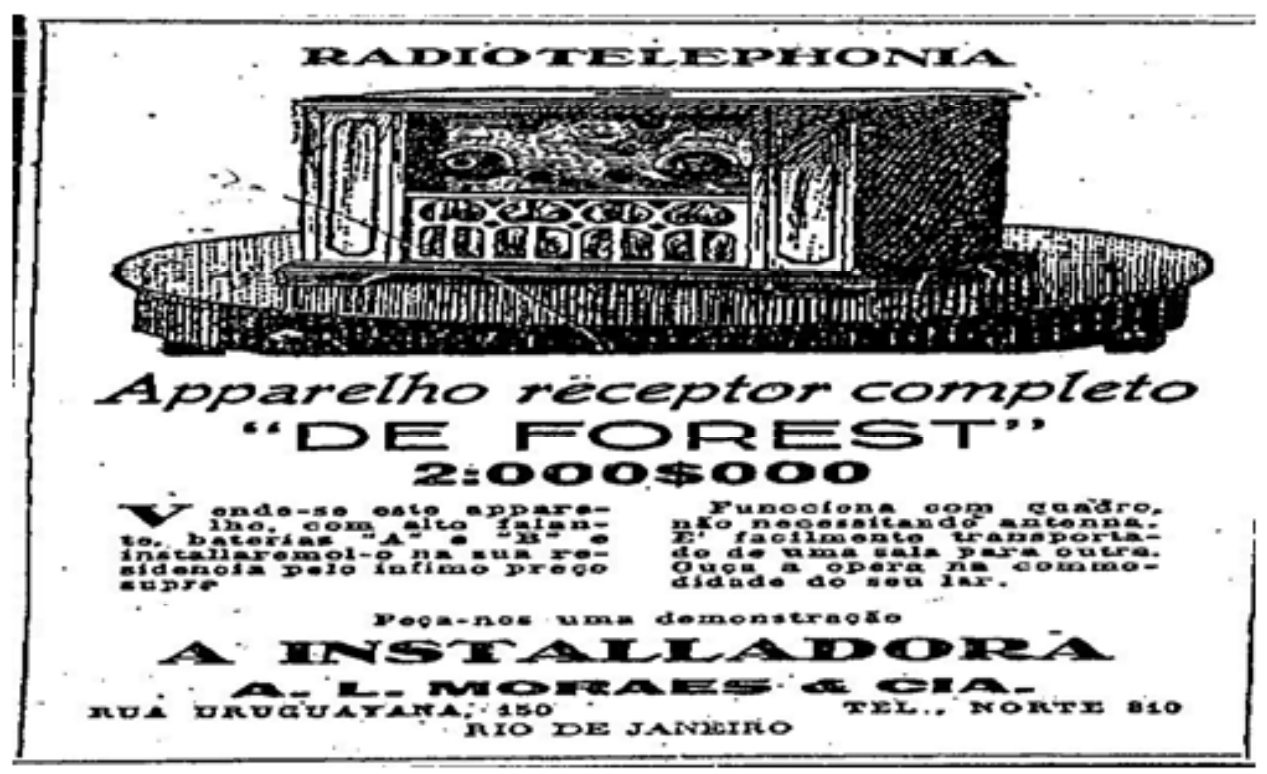

Figura 3 - Fonte: Jornal O Globo, 14/8/1926.

A propaganda ocupou duas colunas centrais de uma página do jornal $O$ Globo. Logo abaixo da ilustração, há um pequeno texto demonstrando as vantagens do aparelho, entre elas o preço e a praticidade. Em seguida, sugeriam que o potencial comprador podia tirar todas as dúvidas que ainda pairavam sobre a nova tecnologia pedindo uma demonstração: "Peça-nos uma demonstração. A Installadora". Em seguida, traz o endereço e o telefone da loja revendedora da marca "De Forest".

Além dessas informações de caráter imediato, há ainda uma frase que sobressai na propaganda: "Funciona como um quadro, não necessitando de antena. É facilmente transportado e uma sala para outra. Ouça a ópera na comodidade do seu lar".

No texto podemos perceber claramente três funções de escuta e de inserção da tecnologia no cotidiano do público: a primeira diz respeito ao aspecto do novo meio como um artefato decorativo; a segunda enfatiza a portabilidade do veículo, o que permitiria o seu deslocamento por diversos ambientes; e a terceira destaca a comodidade que, em função de características técnicas, poderia ser conseguida na interação com o meio.

Dependendo de seu formato físico, o rádio ia se incorporando de maneira totalmente diferenciada à vida dos indivíduos e fornecendo sentidos distintos as suas práticas cotidianas. $\mathrm{O}$ indivíduo que escutava rádio com fone de ouvido, por exemplo, optava por uma escuta individualizada. Ouvia o rádio sozinho, atribuindo ao meio um sentido diferente daqueles que construíam aparelhos que incorporavam amplificadores e alto-falantes, já que esses artefatos tecnológicos permitiam a amplificação do som e, portanto, pressupunham uma escuta de natureza coletiva. Já o aparelho com as peças acopladas internamente, vendido pronto, tinha o formato de um móvel decorativo, fácil de transportar de um cômodo a outro da casa, fornecendo ao ambiente privado uma nova dinâmica: a casa ganhava novos sons, novos ruídos, que poderiam ser ouvidos por várias pessoas ao mesmo tempo e em vários ambientes, acompanhando os indivíduos em seus afazeres diários.

Para os idealistas da campanha de desenvolvimento do rádio no país, no entanto, o formato dos aparelhos era o que menos importava. O que destacavam sempre era a urgência da proliferação da ideia de rádio inserida em qualquer tipo 
de aparato material (vara de bambu ou antena convencional, por exemplo) que possibilitasse a façanha da captação do som a distância. Todos deveriam estar aptos a ter contato com a tecnologia, fosse ela barata ou cara.

[...] pode-se dizer que o amador abastado dono de um receptor que the custou $500 \$$ ou 2 contos, recebe de longe e mais forte, mas não ouve mais apagadamente do que o humilde operário ou jovem estudante que organizou seu posto com uns magros 50 ou 100 mil reis... E claro que cada qual devera escolher a melhor installação compativel com os recursos proprios. (ROQUETTEPINTO, Edgard. In: Gazeta de Notícias, Coluna Radiophonia, 11/05/1923)

No comentário, Roquette-Pinto deixa antever que as formas de escuta são diferentes e dependem, de fato, do tipo de aparelho construído. O receptor mais caro, diz ele, consegue captar sinais mais longínquos e mais fortes do que o mais barato. No entanto, o som, em ambos, pode não trazer a nitidez bem definida das mensagens, mas o que importa, nesse caso, é a aprendizagem correta da forma como acoplar as peças aos aparelhos. Sem as noções técnicas, tanto o aparelho caro quanto o barato poderiam não funcionar corretamente. Era essencial, portanto, ensinar a todos os cidadãos as técnicas indispensáveis para a montagem dos aparelhos.

Vejamos então que ha de fazer o que estiver disposto a praticar [...] porque, de facto, todas as pessoas medianamente intelligentes, até mesmo os que não sabem ler, podem ser, sem exagero, consideradas amadores do T.S.F. em estado potencial... Ainda mais os que se julgam indiferentes, sao amadores sem o saber! (ROQUETTE-PINTO, Edgard. In: Gazeta de Notícias, Coluna Radiophonia, 11/05/1923, original sem grifo)

Como esclarece Roquette-Pinto nesta passagem, qualquer um, mesmo os que não sabiam ler, poderia ser amador em potencial. A tecnologia, se praticada, estaria ao alcance de todos. Mas, para que todos pudessem praticá-la, era necessária sua disseminação.

Para Roquette-Pinto, o rádio seria fundamental para retirar o "povo da escuridão mental", levando adiante um projeto mais amplo de natureza educativa, bem de acordo com o ideário do conservadorismo brasileiro, que acreditava no ideário iluminista de que a cultura letrada seria um meio de "iluminar" o povo que vivia, até a chegada do rádio, à margem do saber erudito.

Assim, no nosso entendimento, o projeto de edição da revista Radio, publicada de 1923 a 1926, por iniciativa do próprio Roquette-Pinto e do grupo que estava a frente do projeto de implantação e disseminação da ideia de rádio no Brasil, cumpre com dois objetivos centrais: o primeiro deles diz respeito à multiplicação das formas de propagação da nova tecnologia, funcionando a revista como loci privilegiado para a alfabetização tecnológica dos letrados. O segundo insere-se no projeto mais amplo de construir um discurso em uníssono entre os próprios pares sobre a importância educacional/cultural/política de uma nova tecnologia ainda desconhecida para a maioria.

A revista se dirige, sobretudo, para aqueles que poderiam amplificar o discurso dos que estavam empenhados na criação do rádio. Para isso, era preciso materializar a tecnologia tornando o meio uma realidade plausível. Esta é uma das razões pelas quais, entre o conteúdo dominante da publicação, sobressaem artigos que ensinam as múltiplas técnicas para a construção de aparelhos, ao lado de outros de cunho científico que alardeavam as descobertas sobre as possibilidades da radiotelefonia. 
${ }^{1} \mathrm{O}$ governo brasileiro solicitava que os amadores registrassem seus aparelhos e pagassem uma taxa junto ao Departamento de Correios e Telégrafos, no intuito de "obter dados concretos sobre o desenvolvimento do rádio no país e de contribuir para esse crescimento". A revista Radio publicava o formulário a ser preenchido pelos amadores e fornecia o passo a passo para o registro.
No primeiro número de Radio: revista quinzenal de divulgação scientifica havia artigos referentes ao funcionamento da Rádio Sociedade, sua programação, seus sócios, seus princípios norteadores, além de outras notícias sobre o papel do rádio no Brasil. Transcreve ainda as normas que obrigam os radioamadores a registrar seus aparelhos para fins estatísticos ${ }^{1}$. Os textos, em sua maioria, objetivam mostrar que rumo tomará o rádio no país a partir da criação da Rádio Sociedade do Rio de Janeiro.

A década de 1920 marca um período de consolidação de múltiplas transformações na imprensa brasileira, que ocorrem desde a virada do século XIX. Nesse momento, proliferam também algumas publicações especializadas, editadas por empresas e vendidas em banca, para divulgar seus produtos e serviços. Exemplos disso são a revista Sul América (da companhia de seguros de mesmo nome), a revista da Cia Antártica Paulista (pertencente ao grupo fabricante de cervejas) e a Revista da Light (da empresa Light and Power, que explorava os serviços de eletricidade e telefonia na cidade), entre uma dezena de outras publicações. Do ponto de vista técnico, as modernas possibilidades de impressão permitem o aparecimento de jornais e revistas com tiragens elevadas, dotados de todos os aparatos necessários a sua divulgação maciça. A criação da primeira revista ilustrada (O Cruzeiro, em 1928) fornece uma espécie de senha para a consolidação de um período de bruscas transformações na imprensa, não só no que diz respeito à quantidade de novos periódicos que surgiam, como também quanto à forma de produção de conteúdos.

Também os periódicos mais importantes da cidade implantavam outros artefatos tecnológicos que mudam significativamente a maneira como se produzem jornais: máquinas linotipos capazes de substituir o trabalho de até 12 das antigas composições manuais; máquinas de imprimir capazes de "vomitar" de 10 a 20 mil exemplares por hora; máquinas de fotografar capazes de reproduzir em imagens o que antes apenas podia ser descrito... (BARBOSA, 2007, p. 22)

Na década de 1920, existiam em todo o país cerca oitocentos periódicos e a expressiva proliferação dos títulos pode ser explicada por inúmeros motivos, entre os quais se destacam o desenvolvimento urbano acelerado, cisões políticas, aperfeiçoamentos tecnológicos e certa especialização dessa imprensa.

Mas talvez o movimento mais importante da década no Brasil tenha sido a implantação do rádio, primeiramente como artefato tecnológico a procura de um conteúdo que só se definiria nas décadas seguintes, também em função dos múltiplos usos que dele fez o público. Músicas ligeiras, programas de auditório, enfim, a multiplicação das formas de conversação do público mediadas por fios, alto-falantes, válvulas, antenas, tudo isso reunido numa caixa sonora, passaria a ser o conteúdo dominante amplificando formas de oralidade existentes no ambiente cotidiano do público (FERRÃO NETO, 2010).

Ferrão Neto destaca ainda a cultura impressa que prolifera a partir do início do século XX e mostra a circularidade dos diferentes modos de comunicar, criar representações de mundo e de novos sentidos para a vida. Em um diálogo permanente com a palavra impressa, o som passa a fixar padrões de comportamento, de saber e de conhecimento oralmente preponderantes. "Há uma circularidade entre o oral e o escrito e entre o rádio e a mídia impressa..." (Id. ibid., p.244)

A função da revista Radio, através da palavra impressa, aguçando o sentido do olhar, era, portanto, levar os leitores a também serem ouvintes. Por ser uma tecnologia nova, com pretensão de expandir-se nacionalmente, o rádio deveria usar múltiplos recursos para amplificar seu alcance. Não bastava criar as emissoras, 
multiplicar o alcance de suas antenas. Era preciso que houvesse um público vasto e heterogêneo e para isso eram necessárias estratégias de natureza política e comunicacionais. Assim, a disseminação da maneira de construir os aparelhos insere-se nessa dupla função.

Apenas a título de exemplo, citamos o artigo assinado por Henrique Morize, intitulado "Apparelho automático para a recepção do signal de SOS", que ensinava a construir um aparelho de última geração capaz de produzir e captar sinais sonoros de socorro. Mais uma vez, torna-se evidente a função da revista de expandir o conhecimento técnico sobre a radiotelefonia. A publicação transformava-se também numa espécie de manual, permitindo o armazenamento da informação e facilitando a recuperação das mensagens para aqueles que se interessavam pelo tema, já que oferecia além de um passo a passo descritivo, o esquema dos circuitos.

Em principio, o apparelho consiste em um relais "differido", que só entra em funcionamento um pouco depois de recebidos os signaes e si estes durarem por certo espaço de tempo. Os relais elementares, cujo conjunto constitui o apparelho, estão providos de um systema de fechamento mutuo e automático, connectando-os por tal fórma entre si, que o primeiro desses relais, o qual corresponde á letra S inicial, letra telegraphicamenteconstituida por três pontos, entra em funcionamento, logo que tenham chegado esses três pontos, e tranca a passagem de qualquer signaldifferente dos três traços, correspondente á letra O.... (MORIZE, Henrique. Apparelho automático para a recepção do signal de SOS. In: Coletânea da revista Radio, n. 13-24, abril a outubro de 1924)

A revista Radio, ao transformar o imaginário sobre o veículo em materialidade, deixava clara sua intenção de incentivar a prática de ouvir rádio também através do conhecimento da nova tecnologia. Nesse sentido, representa a tentativa dos letrados de dominar um mundo que ainda não conheciam, o da técnica da radiotelefonia. Pela apropriação da tecnologia tentam aprisionar os conteúdos do novo meio na esfera simbólica do letramento.

Logo no primeiro exemplar, Roquette-Pinto enfatiza que o papel de Radio era facilitar o conhecimento do novo meio de forma indiscriminada, ou nas suas palavras, "facilitar [...] sua entrada em todas as camadas da população do país".

Radio - hoje entregue á sua sorte, está certa da força incoercível do progresso, segura de que nossos patrícios não deixarão por mais tempo de voltar a attenção para os problemas sociaes que a radiotelefonia vem agitar, facilitando, de modo novo e inesperado, sua entrada em todas as camadas da população do paiz. (Revista Radio, 15/10/1923, p. 5, original sem grifo.)

Os intelectuais se apropriaram da revista com o objetivo de construir um discurso unificado sobre o rádio, com a intenção de popularizá-lo, desde que fossem eles os autorizados para isso. No entanto, abriam brechas para a criação de novos grupos de radioamadores, quando a Rádio Sociedade passa a oferecer, a quem se interessasse, protótipos de aparelhos. Em cada exemplar, a revista publicava o seguinte aviso em letras garrafais:

Quem precisa de clichês de rádio?

Na nossa redacção, das 9 horas da manhã ás 6 horas da tarde, os interessados poderão adquirir, pelo preço do custo, clichês de eschemas e gravuras, excellentemente montados e em perfeito estado de conservação. (Coletânea da revista Radio, n. 13-24, abril a outubro de 1924) 
A inventividade na criação de formatos de aparelhos era, portanto, incentivada pela revista. Com essa estratégia, intensificava-se o contato dos cidadãos com as múltiplas formas que o rádio poderia adquirir, dotando o novo meio de múltiplos sentidos e formas de escuta, como já assinalamos. O rádio, pela apropriação tecnológica dos indivíduos, ia sendo representado com diversas faces materiais, sendo primeiramente "rádios".

E as imagens desses múltiplos rádios são encaminhadas pelos próprios ouvintes/ inventores à emissora, materializando não apenas o contato auditivo que tinham com o meio, mas sobretudo o contato tátil. Era pelas mãos dos ouvintes, como inventores, que a escuta primeiro chegava até eles, como no caso de Lourival Santos, que enviou à emissora o desenho do rádio que construíra.

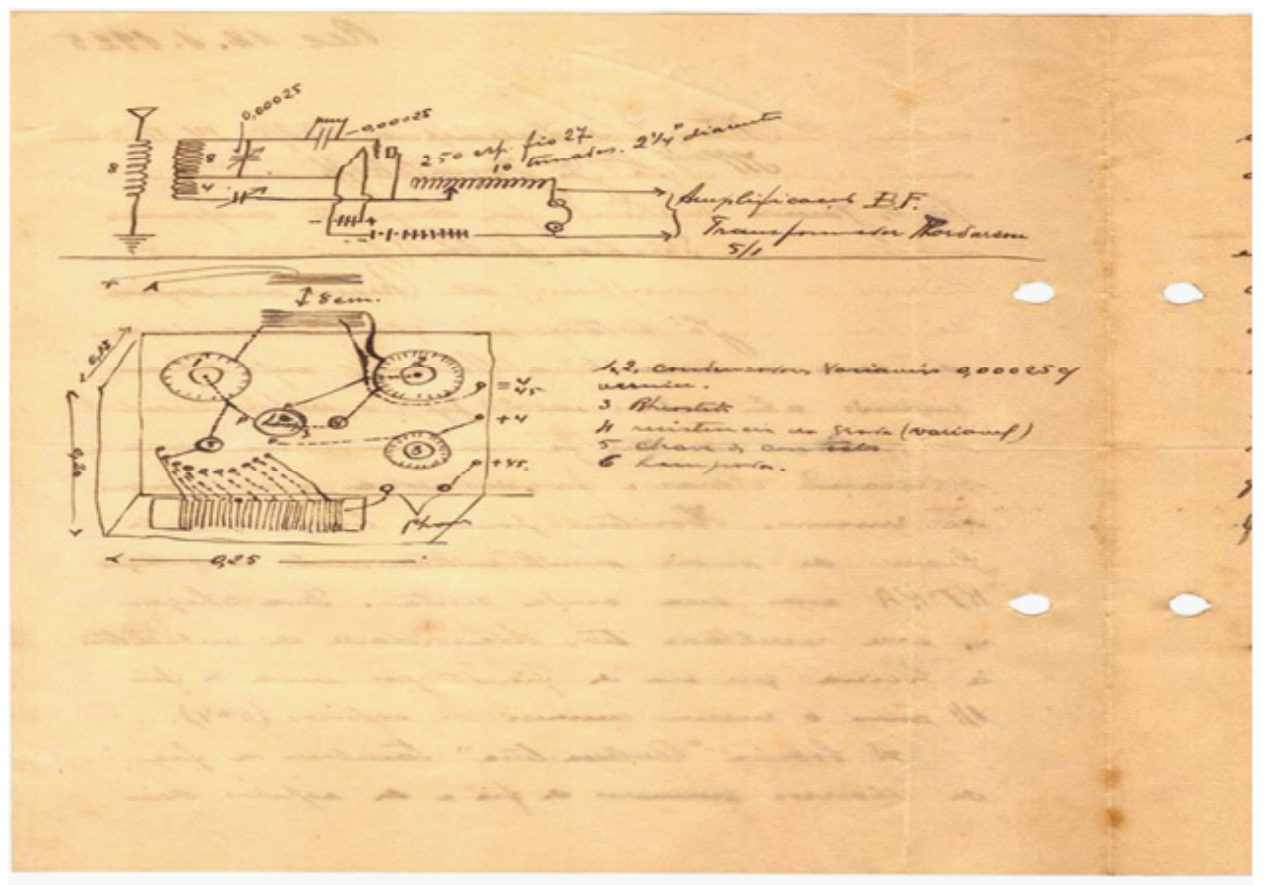

Figura 4 - Fonte: Documento A.03-0193 - Imagem: 0753. Disponível em WWW.fiocruz/ radiosociedade.br.

No artigo intitulado "A Praga dos Alto-Falantes" (Anexo 1), o engenheiro João Curia assegura que, com a adoção de determinadas técnicas, os radioamadores obteriam, certamente, um som "além de suficientemente intenso", "de uma clareza admirável e de uma pureza sem igual”. E continua:

No arco cantante a voz do cantor apparece tão clara que da a impressão do próprio cantor presente na sala [...] é a propriedade que tem o arco cantante de eliminar totalmente a estática, as descargas atmosphericas. (Coletânea da revista Radio, n. 13-24, abril a outubro de 1924. Disponível em www.fiocruz.br/ radiosociedade,)

No "arco cantante", a voz do cantor apareceria de forma tão audível que se teria a impressão de que ele estava, em presença, na sala do ouvinte. Portanto, está na dependência da tecnologia a sensação de estar em presença a partir da percepção sonora. Com ruídos, chiados, provocados pela estática ou por descargas atmosféricas, o som seria atravessado por interferências, transformando-se em artificial e numa espécie de ausência.

Havia, pois, uma busca pela melhor tecnologia de forma a tornar o som presente, isto é, reproduzir via aparelhos radiofônicos aquilo que de mais próximo o ouvido humano captava em presença de um outrem. O objetivo, em última instância, era transformar o resultado de uma oralidade secundária no mais próximo da 
${ }^{2}$ Sobre oralidade primária e secundária cf. ONG, 1998. oralidade primária (ONG, 1998)². Segundo Ferrão Neto (2010), a mistura de sons naturais e manufaturados faz aumentar e intensificar a perspicácia na escuta por parte dos ouvintes, desenvolvida no contato com a palavra, a música, os efeitos sonoros e os intervalos de silêncio igualmente fabricados e imaginados pela técnica.

Há que considerar ainda que a palavra impressa, no caso do artigo citado, produziu sensações e representações relativas à oralidade, ao descrever os efeitos do altofalante. O som, no entanto, não tem sede, nem rastro. (ONG, 1998, p. 42)

Com o mesmo sentido de tornar a técnica acessível, ampliando também desta forma as possibilidades sonoras do rádio, que passaria a ser possível no cotidiano de muitos, o artigo "Primeiras noções de radiotelefonia e radiotelegrafia", assinado pelo engenheiro Othon Leonardos, indica aos amadores as peças imprescindíveis para a montagem de um receptor: antena, detector, fone e terra. Além disso, o engenheiro, que publicaria em breve o primeiro manual didático de T.S.F., autoriza a revista a publicar o primeiro capítulo de seu livro.

Para que os amadores tão justamente desejosos desse livro, que já não nos tardava, possam avaliar de maneira feliz e intelligente, com que elle está sendo feito, Radio inicia hoje a publicação do primeiro capítulo. (Coletânea da revista Radio, n. 13-24, abril a outubro de 1924. Disponível em www..fiocruz.br/ radiosociedade)

O engenheiro fornece aos radioamadores um desenho dos aparelhos de radiotelegrafia e de radiotelefonia. Afirma ainda que o mesmo receptor poderá realizar operações tanto de radiotelegrafia quanto de radiotelefonia. $\mathrm{Na}$ imagem a seguir, publicada junto ao artigo, percebe-se a preocupação com o didatismo e o papel que a revista teve nessa difusão dos saberes práticos que possibilitariam também a formação de público para o veículo. Sem a adesão do público, como o próprio Roquette-Pinto salientou, não haveria consolidação do rádio no Brasil e, com isso, a possibilidade de modernização do país, na sua concepção, se tornaria remota.

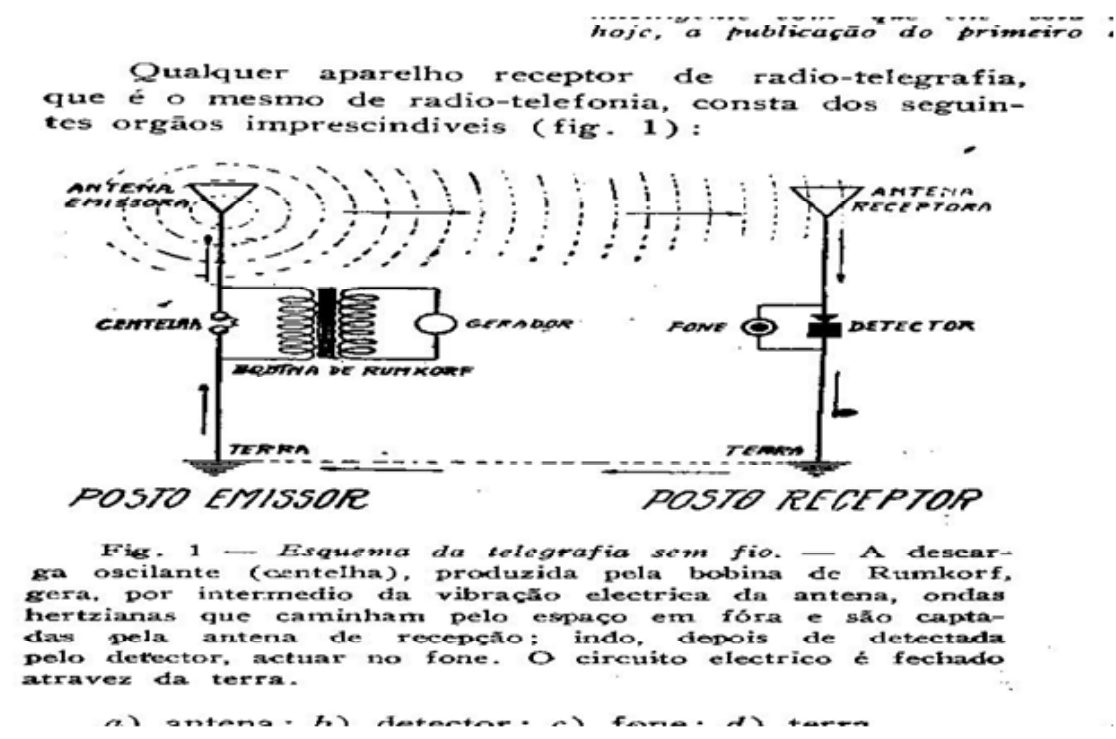

Figura 5 - Fonte: Coletânea da revista Radio, n. 13-24, abril a outubro de 1924

Além de artigos como o de Othon Leonardos,o periódicomantinha com os leitores um diálogo permanente em relação à construção dos receptores, na coluna "Seção perguntas e respostas". Nela, os radioamadores podiam enviar aos editores qualquer dúvida sobre a construção ou funcionamento dos aparelhos. 


\section{Seção Perguntas e respostas}

Sr. Epaminondas da Silva (Recife)

Deseja dados para a construção de um transformador de radio-frequencia.

Resposta:

O que o Sr. Pede é um pouco longo para ser explicado nessas columnas e será publicado em um artigo na primeira opportunidade.

Sr. Marcelino Pereira (Rio)

Deseja saber o que terá acontecido a uma lâmpada De Forest que se apagou de repente, numa noite em que havia muitas descargas.

Resposta:

O que aconteceu á lâmpada é que, pura e simplesmente, Ella se queimou por ter chegado ao limite de vida do filamento. Para outra vez, não faça brilhar tanto a lâmpada, que isto pouco adeanta.

(Coletânea da revista Radio, n. 13-24, abril a outubro de 1924. Disponível em www.fiocruz.br/radiosociedade)

Mas não eram só as informações essenciais sobre a montagem da tecnologia do rádio que tinham espaço na revista. Havia espaço também para curiosidades científicas sobre as maravilhas realizadas pelas ondas do rádio. $O$ artigo "Ondulações radioelétricas" narra as façanhas de dois professores norteamericanos, FredericKorf e M. William Zeutler, da Academia Wilfred de Nova York, em relação ao aperfeiçoamento de uma máquina produtora de ondulações radioelétricas. Observa-se, no texto, a presença do fascínio pela bricolagem, quando indicam a possibilidade de conduzir correntes fracas com a utilização de uma salsicha e, de correntes fortes, com uma lingüiça. Além disso, o aparelho era composto por seis ferros quentes que originalmente serviam para ondular os cabelos das mulheres...

O apparelho é bastante simples e não comporta batterias de accumuladores tão pezadas de carregar, nem lâmpadas triodicas de luz tão ephemera. Nada disso. O apparelho compõe-se de meia dúzia de ferros quentes para ondular cabellos de mulher. Não há muito tempo foi publicado nas columnas desta revista um apèremetresuinogeneris, feito com uma salsicha para as correntes fracas e com uma lingüiça no caso de correntes mais intensas. Um assíduo leitor desta revista, achando incompativel com a arte radioeletrica as iguarias acima citadas, levou como resposta que quando Saussure descreveu o seu apparelhoclassico, encontrado em qualquer manual de physica, houve também muita gente que julgasse pilheria querer medir a humidade do ar servindo-se de um cabello de mulher. (Coletânea da revista Radio, n. 13-24, abril a outubro de 1924. Disponível em www.fiocruz.br/radiosociedade, original sem grifo)

Entretanto, o caráter didático na divulgação das possibilidades técnicas do rádio não se restringiu à revista Radio. Em 1923, o jornal Gazeta de Notícias criou uma coluna com o propósito de divulgar amplamente o novo meio. Em sua primeira edição, em 19/4/1923, "Radiophonia", como a coluna foi nomeada, explicita seu intento de contribuir para a consolidação do veículo.

A Gazeta honra-se de ser, no Brasil, o primeiro jornal que dedica especialmente um trecho de uma de suas paginas a este assumpto relevante: tanto mais quanto esta secção está entregue a um dos mais talentosos e mais cultos dos nossos jovens scientistas. Maior honra, porém, será a nossa, se virmos toda a imprensa brasileira collaborar nesta obra necessária de divulgação e de incitamento. (Gazeta de Notícias, 19/4/1923)

O personagem a que o jornal se refere como "um dos mais talentosos e mais cultos dos nossos jovens cientistas" era, precisamente, Roquette-Pinto. Dois anos 
depois, no mesmo ano de sua fundação, também o jornal $O$ Globo criaria uma coluna dedicada ao rádio: "O Globo na T.S.F”.

Tal como a revista Radio, essas colunas passam a explicar a funcionalidade dos receptores. Em maio de 1923, Roquette-Pinto publica a carta de um amador em que se queixava de não conseguir ouvir a hora certa emitida pelo Observatório: "Como hei de fazer, Sr. Redactor, para acertar o meu relógio, utilizando-me, ao menos para isso, o meu custoso Radiolo?" (Coluna Radiophonia, Gazeta de Notícias, 14/5/1923) Em resposta, Roquette- Pinto ensina:

De hoje em diante não precisará perguntar mais as horas ao vizinho, para acertar o relógio de casa [...] Ás 10 horas, 55 minutos e 55 segundos, começam os signaesproprios, que terminam ás 11 horas. É facil reconhecê-los pois são muito mais longos que os do telegrapho. (Coluna Radiophonia, Gazeta de Notícias, 14/5/1923)

Em outra coluna, também publicada em 1923, Roquette-Pinto responde às cartas de dois radioamadores em relação à construção de seus aparelhos e ainda faz referências às propriedades da radiotelefonia. " $E$, se nós hoje, com o phonio ao ouvido, num dia de sol lindo e glorioso, podemos acompanhar o desenrolar de uma tempestade, a centenas de kilometros, e ouvi-la que vem chegando..." (Coluna Radiophonia, Gazeta de Notícias, s/d 1923)

Roquette-Pinto destaca, portanto, o fascínio que a radiotelefonia proporcionou ao deslocar os sons no tempo e no espaço. Ampliando e dotando de novos sons a paisagem sonora da cidade, a sonoridade tecnológica mediada pelo rádio tornaria possível que na esquina de uma rua, no centro de uma cidade moderna, não houvesse distância, somente presença. (SCHAFER, 2001, p. 72) A técnica permitia a ampliação dos sons, mudando também a relação dos indivíduos com o mundo que os cercava. O que fascinava Roquette-Pinto era o poder de a radiotelefonia alcançar, ao mesmo tempo, lugares jamais imaginados, indicando a existência de uma presença sonora, que tornaria, em imaginação, o mundo mais próximo.

Mas, enquanto os nossos maiores não podiam avisar pelo sino senão os vizinhos da freguesia, nós outros, rimos e choramos para a terra na mesma hora, como se habitassemos todos o mesmo ponto do Universo. (Coluna Radiophonia, Gazeta de Notícias, 1923)

A coluna O Globo na T.S.F, tal como o que já vinha ocorrendo na Gazeta de Notícias, também assumiu o papel de divulgar as maravilhas técnicas da radiotelefonia. Em sua estreia, em 1925, publicou a imagem do circuito interno de um aparelho receptor de uma válvula e o desenho de sua aparência externa. No texto, o jornal assume o papel de ser mais um veículo que luta pelo desenvolvimento do rádio no país.

Com o espantoso desenvolvimento que vae tendo a radiotelegraphia e a radiotelephonia em todo o mundo, fácil era prever o apparecimento neste jornal de uma secção que se dedicasse inteiramente a esse assumpto.

Quer a radiotelephonia, quer a radiotelegraphia, conta entre nós numerozosenthusiastas, aos quaespretendemos auxiliar fornecendo dados práticos para a construcção de apparelhos, respondendo ás consultas que nos fizerem e transmittindo-Ihestambem as novidades mais recentes que surgirem aqui e no estrangeiro. 
Enfim, procuraremos desenvolver em nosso povo o gosto pelo T.S.F, que constitui uma das maravilhas da sciencia moderna. (Coluna O Globo na T.S.F, Jornal O Globo, 1925, original sem grifos)

A imprensa, como já enfatizamos, através da criação dessas colunas, assumiu o papel de difusora das novidades do rádio. Percebe-se a relevância que possuía a vulgarização da nova tecnologia, a fim de "desenvolver em nosso povo o gosto pelo T.S.F."

Nesses periódicos havia, pois, a intenção de desmistificar o saber científico e torná-lo próximo também dos letrados. Moreira e Massarani (2003) analisam a década de 1920 como um período de aumento significativo das iniciativas de divulgação científica, que se tornou presente em jornais, revistas e livros e também em conferências periódicas, abertas ao grande público. Com a criação de diversas instituições científicas e a valorização social da ciência e do cientista, para as autoras, a elite intelectual ligada à ciência acreditava na importância de se posicionar positivamente junto ao público para permitir o desenvolvimento de uma ciência pura.

Os jornais, por sua vez, ávidos por novidades, incorporaram, no caso do rádio, a missão de serem multiplicadores do conhecimento científico e tecnológico, sem o qual, acreditava-se, não haveria a expansão do veículo.

Asnarrativas dos periódicos evidenciam certo encantamento comas possibilidades da radiotelefonia. A imprensa narrava as novas sensações possibilitadas pela primeira tecnologia capaz de transmitir o som pelo espaço e fornecia ensinamentos sobre os meios técnicos para os cidadãos letrados se inserirem nessa nova experiência. Como escreveu Roquette-Pinto, entusiasticamente, "Por toda parte as maravilhas do telephonio sem fio empolgam o espirito das populações..." (Radiophonia, Gazeta de Notícias, 19/4/1923)

A imprensa consolidou em sua narrativa o rádio como novidade e o público letrado aderiu ao movimento de construção/aquisição de aparelhos. Isso nos leva a refletir sobre as formas de compreensão e as apropriações do público, que segundo Chartier (2007, p. 43) dependem de efeitos de sentido para os quais apontam as próprias obras, os usos e significados impostos pela sua forma de publicização e circulação.

\section{Referências Bibliográficas}

BARBOSA, Marialva. História cultural da imprensa: Brasil. 1900-2000. Rio de Janeiro, Mauad X, 2007.

BOURDIEU, Pierre. A economia das trocas simbólicas. São Paulo, Perspectiva,1987.

CHARTIER, Roger. A história ou a leitura do tempo. Belo Horizonte, Autêntica Editora, 2009.

FERRÃO NETO, José. Mídia, oralidade e letramento no Brasil: vestígios de um mundo dado a ler. Tese de doutorado apresentada ao Programa de Pós-Graduação em Comunicação da Universidade Federal Fluminense, UFF, 2010.

FERRARETO, Luiz Artur. Rádio: o veículo, a história e a técnica. Porto Alegre, Sagra Luzzatto, 2000.

MOREIRA, Ildeu de Castro \& MASSARANI, Luiza. A divulgação científica no Rio de Janeiro: um passeio histórico e o contexto atual. In: revista Rio de Janeiro, n. 11, 
set-dez 2003.

ONG, W.J. Oralidade e cultura escrita: a tecnologização da palavra. Campinas, Papirus, 1998.

SCHAFER, R. Murray. A afinação do mundo. São Paulo, Editora UNESP, 2001.

\section{Fontes consultadas}

- Coletânea de artigos da revista Radio dos números 13 ao 24, ano de 1924. Disponível no acervo da Rádio MEC.

- Exemplares números 1 e 2 da Revista Radio, 15/10/1923 e 1/11/1923. Disponíveis na Biblioteca Nacional.

- Documentos da Rádio Sociedade do Rio de Janeiro digitalizados pelo projeto Memória da Rádio Sociedade, disponíveis em www.fiocruz.br/radiosociedade

- Documentos do acervo de Edgard Roquette-Pinto da Academia Brasileira de Letras

- Gazeta de Notícias, coluna Radiophonia, ano de 1923. Disponível na Biblioteca Nacional e alguns números digitalizados no sitewww.fiocruz.br/radiosociedade

- Jornal O Globo, coluna “O Globo na T.S.F.", de 1925 a 1930. Disponível no acervo do jornal O Globo. 